Artikel Riset

DOI : 10.33751/jf.v10i1.1938
Fitofarmaka Jurnal Ilmiah Farmasi

Vol.10, No.1, Juni $2020: 54-64$

p-ISSN : 2087-9164 e-ISSN : 2622-755X

\title{
EVALUASI PEMBERIAN ANTIBIOTIK PADA PASIEN DEMAM TIFOID DI INSTALASI RAWAT INAP RUMAH SAKIT AZRA KOTA BOGOR
}

\author{
${ }^{1}$ Dewi Oktavia Gunawan*, ${ }^{2}$ Lusi Indriani, ${ }^{3}$ Dr.dr. Mira Dewi. M.si, \\ ${ }^{1,2}$ Program Studi Farmasi FMIPA Universitas Pakuan Bogor PO Box 452 Bogor 16143, \\ ${ }^{3}$ Institut Pertanian Bogor J1. Raya Dramaga Kampus IPB Dramaga Bogor 16680 \\ *E-mail: dewioktaviag@yahoo.co.id
}

\begin{abstract}
ABSTRAK
Demam tifoid adalah penyakit yang disebabkan oleh bakteri Salmonella typhi atau Salmonella thyposa dari genus Salmonella. Gejala penyakit demam tifoid biasanya berkembang dalam1-3 minggu pasca terpapar bakteri yang ditandai demam tinggi, malaise, sakit kepala, sembelit atau diare, bintik-bintik kemerahan pada dada, serta pembesaran limpa dan hati. Untuk memastikan penyebab demam tifoid pemeriksaan laboratorium mikrobiologi sangat diperlukan. Idealnya adalah test Widal dan kadar leukosit, selain itu perlu diperhatikan juga gejala-gejala klinis seperti suhu tubuh, tingkat kesadaran, nyeri perut, mual atau muntah dan nafsu makan. Tujuan dari penelitian ini adalah menilai efektivitas antibiotik yang digunakan pasien yang menderita demam tifoid. Penilaian dilakukan dengan melihat hasil widal test, kadar leukosit, suhu tubuh, tingkat kesadaran, nyeri perut, mual atau muntah, dan nafsu makan. Penelitian dilakukan dengan cara terlebih dahulu mengumpulkan data sekunder dari rekam medis pasien, register pasien, dan resep obat pasien yang terdiagnosis demam tifoid yang disesuaikan dengan kriteria inklusi, kemudian secara non-eksperimental dideskripsikan dengan pendekatan retrospektif. Hasil penelitian menunjukkan bahwa pemberian antibiotik terbukti efektif terhadap widal test sebanyak $85 \%$, terhadap kadar leukosit sebanyak $97 \%$, terhadap suhu tubuh pasien sebanyak 94\%, terhadap kesadaran pasien sebanyak $100 \%$, terhadap nyeri perut pasien sebanyak $100 \%$, terhadap mual dan muntah pasien sebanyak $99 \%$, dan terhadap nafsu makan pasien sebanyak $100 \%$.
\end{abstract}

Kata Kunci: Evaluasi, antibiotik, demam tifoid, Rumah Sakit Azra

\section{THE EVALUATION OF ANTIBIOTIC ADMINISTRATION TO TIFOID FEVER PATIENTS AT AZRA HOSPITAL INPATIENT INSTALLATION IN BOGOR CITY}

\begin{abstract}
Typhoid fever is a disease caused by the bacterium Salmonella typhi or Salmonella thyposa of the Salmonella genus. Symptoms of typhoid fever usually develop within 1-3 weeks after exposure to bacteria characterized by high fever, malaise, headaches, constipation or diarrhea, reddish spots on the chest, and enlargement of the spleen and liver. To ascertain the cause of typhoid fever, a microbiological laboratory examination is needed. Ideally, the Widal test and leukocyte levels should be noted, besides clinical symptoms such as body temperature, level of consciousness, abdominal pain, nausea or vomiting and appetite. The purpose of this study was to assess the effectiveness of antibiotics used by patients suffering from typhoid fever. Assessment is done by observe at the results of the Widal test, leukocyte levels, body temperature, level of consciousness, abdominal pain, nausea or vomiting, and appetite. The study was conducted by first collecting secondary data from the patient's medical records,
\end{abstract}


patient registers, and prescriptions for patients diagnosed with typhoid fever that were adjusted to the inclusion criteria, then non-experimentally described with a retrospective approach. The results showed that the administration of antibiotics proved effective against $85 \%$ Widal test, 97\% leukocyte levels, $94 \%$ patient temperature, $100 \%$ patient awareness, $100 \%$ abdominal pain, patient's nausea and vomiting as much as $99 \%$, and the patient's appetite as much as $100 \%$.

Keywords: Evaluation, antibiotics, typhoid fever, Azra Hospital

\section{PENDAHULUAN}

Demam tifoid termasuk salah satu jenis penyakit infeksi yang tidak bisa dianggap ringan. Insidensi demam tifoid bervariasi di tiap daerah dan biasanya terkait dengan sanitasi lingkungan. Penyakit ini endemik di Indonesia, diperkirakan 800/100.000 penduduk pertahun terserang demam tifoid, ditemukan hampir sepanjang tahun. Perbedaan insiden di perkotaan berhubungan dengan penyediaan air bersih yang belum memadai serta sanitasi lingkungan dengan pembuangan sampah yang kurang memenuhi syarat kesehatan lingkungan (Widodo, 2006). Penyakit demam tifoid merupakan masalah kesehatan khususnya di Indonesia dan negara berkembang lain. Apabila dilihat dari kasus demam tifoid di beberapa rumah sakit besar, kasus demam tifoid menunjukkan kecenderungan yang meningkat dari tahun ke tahun dengan rata-rata kesakitan 500/100.000 penduduk dengan kematian antara $0,6 \%$ 5,0\% (Rampengan, 2013).

Di Indonesia penyakit demam tifoid bersifat endemik. Demam tifoid dan paratifoid termasuk penyakit dengan peringkat ketiga pasien rawat inap terbanyak di rumah sakit Indonesia. Pada tahun 2010 penderita demam tifoid dan paratifoid yang dirawat inap di rumah sakit sebanyak 41.081 kasus dan 274 diantaranya meninggal dunia (Depkes RI, 2011). Kasus demam tifoid banyak terjadi pada anak-anak dan remaja, juga pada usia produktif yaitu usia seseorang yang dalam kegiatan bekerja masih bisa menghasilkan sesuatu, faktor kelelahan dan stamina menjadi bagian penting pada tubuh usia produktif yang dapat terpapar bakteri Salmonella typhi (Rampengan, 2013). Menurut data di RSUD Sukoharjo demam tifoid menjadi penyakit dengan jumlah terbanyak yang dirawat inap di RSUD
Sukoharjo pada tahun 2015 dengan 764 kasus (Wahyu, 2016).

Pengobatan menggunakan antibiotik merupakan obat yang paling banyak digunakan terkait dengan banyaknya kejadian infeksi bakteri yang diderita oleh banyak orang (Juwono, 2004). Sejalan dengan itu antibiotik menjadi obat yang paling sering disalahgunakan atau digunakan secara irrasional sehingga akan menimbulkan kegagalan terapi dan berbagai masalah seperti ketidaksembuhan penyakit, meningkatnya resiko efek samping obat, resistensi, supra infeksi, dan biaya (Sastramihardja, 2001). Oleh karena itu, antibiotik yang digunakan harus sesuai dengan sensitifitas dan infeksi bakterinya. Sejak tahun 1948 kloramfenikol merupakan drug of choice untuk infeksi Salmonella thypi. Keampuhan kloramfenikol pada pengobatan demam tifoid telah diakui berdasarkan efektivitasnya terhadap Salmonella typhi disamping harga obat relatif murah (Hadinegoro, 1999). Pada hasil penelitian sebelumnya di RSUD Kabupaten Sukoharjo tercatat sebanyak 107 kasus dengan parameter penggunan jenis antibiotik terdapat 85 kasus $(75,44 \%)$ sesuai dengan standar terapi dan 22 kasus $(20,56 \%)$ tidak sesuai dengan standar terapi.

Mengingat masih banyaknya kasus pengobatan demam tifoid yang terjadi di Indonesia yang belum sepenuhnya sesuai dengan sensitifitas dan efektifitas terapi antibiotiknya, maka berdasarkan hal tersebut penulis terdorong untuk melakukan penelitian mengenai evaluasi pemberian antibiotik pada kasus demam tifoid sebagai salah satu tanggung jawab farmasis dalam rangka mempromosikan penggunaan antibiotik yang efektif agar tidak merugikan pasien. 


\section{METODE PENELITIAN}

Penelitian ini merupakan penelitian observasional non-eksperimental yang bersifat deskriptif dengan pendekatan retrospektif, dengan tujuan untuk menilai efektivitas antibiotik yang digunakan pasien yang menderita demam tifoid di Instalasi rawat inap Rumah Sakit Azra Kota Bogor tahun 2017. Penelitian dilaksanakan pada bulan Oktober sampai November tahun 2018 di Rumah Sakit Azra Kota Bogor.

\section{Populasi dan Sampel}

Populasi dalam penelitian ini adalah semua pasien yang terdiagnosis tifoid dan yang menjalani pengobatan dengan antibiotik di instalasi rawat inap Rumah Sakit Azra Kota Bogor Tahun 2017. Sampel penelitian ini adalah pasien dewasa yang terdiagnosis demam tifoid dan memenuhi kriteria inklusi.

\section{Kriteria Inklusi dan Eksklusi}

Kriteria inklusi dalam penelitian ini yaitu: a) rekam medik pasien berumur 18-55 tahun yang menerima terapi antibiotik dengan diagnosis tifoid di Instalasi rawat inap Rumah Sakit Azra Kota Bogor periode JanuariDesember tahun 2017, b) Rekam medik pasien dengan diagnosa tifoid tanpa penyakit infeksi penyerta. Kriteria eksklusi dalam penelitian ini yaitu rekam medis pasien dengan resep pasien yang hilang atau tidak lengkap.

\section{Teknik Pengumpulan Data}

Teknik pengumpulan data dalam penelitian ini adalah dengan mengumpulkan data sekunder dari catatan rekam medis serta register pasien yang terdiagnosis demam tifoid yang termasuk ke dalam kriteria inklusi.

\section{Analisis Data}

Analisis data yang digunakan adalah analisa univariat, dimana setelah semua data diolah kemudian data disajikan dalam bentuk persentase dalam tabel distribusi frekuensi untuk menyimpulkan data. Data yang telah dikumpulkan kemudian dianalisis secara deskriptif observasional. Analisis data dilakukan dengan mengelompokkan data yang sudah diidentifikasi sesuai dengan diagnosis masing-masing untuk memperoleh informasi tentang efektivitas penggunaan antibiotik, dilakukan dengan menghitung persentase perbaikan kondisi klinis dan hasil data laboratorium pasien sesudah perawatan.

\section{HASIL DAN PEMBAHASAN \\ Karakteristik Pasien Demam Tifoid}

Berdasarkan data pada Tabel 1 jumlah pasien pada penelitian ini adalah 80 orang. Distribusi jenis kelamin menunjukkan bahwa $63 \%$ pasien perempuan lebih banyak dibandingkan pasien laki-laki dengan persentase $37 \%$. Penelitian ini diperkuat dengan penelitian sebelumnya yang menyatakan bahwa penderita demam tifoid dengan jenis kelamin perempuan lebih banyak yaitu $60 \%$ apabila dibandingkan dengan pasien laki-laki yaitu 40\% (Puspa, 2005). Persentase distribusi usia antara pemuda dan dewasa penuh tidak terlalu jauh berbeda, hal ini berarti bahwa angka kejadian demam tifoid tidak berbeda antara usia pemuda dan juga dewasa penuh (Rampengan, 2013). 
Tabel 1. Distribusi Frekuensi Karakteristik Pasien (Depkes RI, 2006

\begin{tabular}{llcc}
\hline \multicolumn{1}{c}{ Distribusi } & \multicolumn{1}{c}{ Karakteristik } & Frekuensi & $\%$ \\
\hline Jenis kelamin & Laki-laki & 30 & $37 \%$ \\
& Perempuan & 50 & $63 \%$ \\
\hline Usia & 18-35 thn (pemuda) & 28 & $35 \%$ \\
& 36-55 (dewasa penuh) & 52 & $65 \%$ \\
\hline Status pembayaran & Asuransi & 38 & $48 \%$ \\
& Non-asuransi/pribadi & 42 & $52 \%$ \\
\hline Lama rawat inap & 3-5 Hari & 57 & $71 \%$ \\
& >5 hari & 23 & $29 \%$ \\
\hline
\end{tabular}

\section{Karakteristik Penggunaan Antibiotik}

Berdasarkan data pada Tabel 2 menunjukkan penggunaan antibiotika untuk pengobatan demam tifoid di Rumah Sakit Azra Kota Bogor. Antibiotik yang digunakan rata-rata adalah antibiotik injeksi atau rute intravena dimana efek pemberian obat yang lebih cepat dibandingkan dengan rute pemberian lain misalnya rute oral. Antibiotik rute oral yang masih digunakan pada beberapa pasien disebabkan karena adanya pertimbangan manfaat dan resiko dari pemberian obat pada setiap pasien, antara lain obat oral tersebut telah dikenal dan diketahui masih sensitif dan potensial untuk demam tifoid di Rumah Sakit Azra Kota Bogor, selain itu cara pemberiannya yang mudah dan dapat ditoleransi dengan baik oleh pasien. Pengobatan demam tifoid di Rumah Sakit Azra Kota Bogor tidak menggunakan kelompok antimikroba lini pertama (kloramfenikol, ampisilin/amoxicillin dan trimethoprim-sulfametoksazol), akan tetapi menggunakan kelompok antimikroba lini kedua yaitu fluoroquinolone dan sefalosporin. Hal ini karena fluoroquinolone dan sefalosporin mempunyai efikasi dan tingkat kepekaan dengan sensitifitas yang cukup tinggi, selain itu diketahui fluoroquinolone dan sefalosporin lebih cepat menurunkan suhu, lama pemberian yang pendek dan dapat diberikan dengan dosis tunggal serta efektif mencegah relaps (Depkes RI, 2006). Selain itu, fluoroquinolone dan sefalosporin menjadi pilihan karena saat ini antimikroba lini pertama (kloramfenikol) tidak lagi digunakan sebagai obat lini pertama karena berkaitan dengan tingginya tingkat kekambuhan dan efek samping yang ditimbulkan. Efek samping kloramfenikol yang berbahaya yaitu depresi sumsum tulang (myelodepresi) yang dapat menyebabkan penghambatan pembentukan sel-sel darah merah dan anemia aplastik, sehingga pada pengobatan dalam jangka lama dengan dosis tinggi pada terapi demam tifoid perlu dimonitor gambaran darah tepi (Tan dan Rahardja, 2015).

Tabel 2. Karakteristik PenggunaanAntibiotika

\begin{tabular}{lll}
\hline \multicolumn{1}{c}{ Jenis Antibiotik } & \multicolumn{1}{c}{ Dosis } & $\begin{array}{c}\text { Harga per } \\
\text { ampul/tablet }\end{array}$ \\
\hline Ceftizoxime 1000 mg Amp & $2 \times 1000 \mathrm{mg}$ & Rp. 150.000 \\
Cefepime 1000 mg Amp & $2 \times 1000 \mathrm{mg}$ & Rp. 240.000 \\
Ceftriaxone 1000 mg Amp & $1 \times 2000 \mathrm{mg}$ & Rp. 200.000 \\
Levofloxacin A 750 mg Amp & $1 \times 750 \mathrm{mg}$ & Rp. 310.000 \\
Levofloxacin A 500 mg Amp & $1 \times 500 \mathrm{mg}$ & Rp. 300.000 \\
Levofloxacin B 500 mg Amp & $1 \times 500 \mathrm{mg}$ & Rp. 300.000 \\
Cefixime 200 mg tab & $2 \times 200 \mathrm{mg}$ & Rp. 48.000 \\
Pefloxacin 400 mg tab & $2 \times 400 \mathrm{mg}$ & Rp. 20.000 \\
\hline
\end{tabular}




\section{Efektifitas Terapi Antibiotik}

Efektifitas terapi antibiotik dapat dilihat pada tabel 3 diawali dengan persentase tes widal pasien yang tidak atau belum normal sebelum terapi antibiotik, yaitu sebesar $100 \%$. Hal ini berarti bahwa semua hasil positif widal memperkuat dugaan terinfeksi Salmonella typhosa pada penderita (Fatmawati, 2011). Untuk melacak kenaikan titer dilakukan dengan cara menentukan titer aglutinin $\mathrm{O}$ dan $\mathrm{H}$ dengan tes widal yang telah dilakukan sejak tahun 1898.

Tabel 3 juga menunjukkan persentase pasien yang kadar leukositnya tidak atau belum normal sebelum diterapi antibiotik yaitu sebesar 53\%, artinya hanya sebagian pasien yang kadar leukositnya tidak normal, sementara $47 \%$ lainnya memiliki kadar leukosit yang normal. Dewasa ini banyak laporan untuk hitung leukosit kebanyakan dalam batas normal atau leukositosis ringan (Depkes RI, 2006). Secara normal, kadar leukosit pada penderita demam tifoid sangat tinggi atau melebihi ambang batas, namun pada penelitian ini terdapat pasien dengan kadar leukosit yang normal sebelum diterapi antibiotik padahal tingkat infeksi yang diderita cukup tinggi. Hal ini dapat terjadi karena perbedaan respon imun pasien dan tingkat resistensi terhadap bakteri tersebut. Sebagian hasil penghancuran bakteri $S$. typhi dalam proses fagositosis pada akhir minggu kedua dapat dikatakan sudah tidak ditemukan lagi $S$. typhi yang hidup di dalam darah namun masih ada dalam sumsum tulang (Handojo, 2004). Apabila bakteri hidup di dalam sumsum tulang, maka akan mengganggu proses pembentukan sel darah. Berdasarkan hal tersebut memungkinkan keadaan pembentukan leukosit atau sel darah putih terhambat sehingga dapat dimungkinkan terdapat kadar leukosit pasien demam tifoid yang justru normal maupun dibawah batas normal (Farihatun, 2017). Pada hari selanjutnya yaitu hari ke 5 dan ke 7 setelah terapi antibiotik, persentase pasien dengan kadar leukosit normal mengalami peningkatan hingga $97 \%$ yaitu sebanyak 78 pasien, sementara pasien dengan kadar leukosit tidak normal mengalami penurunan hingga 3\% yaitu sebanyak 2 pasien. Hal ini menunjukkan bahwa pemberian antibiotik 97\% menormalkan kadar leukosit dan efektif dalam menghentikan dan memusnahkan penyebaran basil S. typhi. Hasil pengamatan ini tidak jauh berbeda dengan penelitian sebelumnya yang menyatakan bahwa pemberian antibiotik $90 \%$ efektif dalam menormalkan kadar leukosit akibat penyebaran basil $S$. typhi dalam tubuh pasien (Wahyu, 2016).

Hasil efektifitas terapi antibiotik pada Tabel 3 diatas juga menunjukkan persentase pasien yang suhunya tidak atau belum normal sebelum terapi antibiotik yaitu $93 \%$, artinya hampir seluruh pasien mengalami demam akibat infeksi S. typhi, sementara 7\% lainnya suhunya normal. Demam atau panas merupakan gejala utama penderita demam tifoid. Pada awalnya demam kebanyakan samar-samar dilanjutkan dengan suhu yang sering turun naik, tetapi perlu diketahui bahwa demam yang khas atau kemunculan demam tidak selalu ada pada penderita demam tifoid atau demam bisa tidak beraturan (Depkes RI, 2006). Pada awal infeksi, S. typhi masuk ke saluran pencernaan dan berkembang biak dengan cepat. IgA merupakan immunoglobulin yang ada pada pencernaan, immunoglobulin jenis ini selanjutnya merespon adanya bakteri tersebut dalam saluran pencernaan. Ketika IgA tidak hadir, bakteri S. typhi akan menempel pada dinding usus, menembus epitel usus menuju lamina propia (Playfair \& Chain, 2009). Selanjutnya $S$. typhi ada yang difagosit oleh sel fagosit terutama makrofag, namun karena kapsul Vi yang dimiliki S. typhi sangat kuat, maka bakteri ini sebagiannya dapat hidup dan berkembang biak, kemudian dibawa ke ileum terminalis dan melalui saluran getah bening dibawa ke kelenjar limfe mesenterium. Melalui duktus thoracicus, S. typhi kemudian masuk ke aliran darah (Fase stadium bakterimia I/masuknya bakteri ke dalam darah I) dan diperangi oleh IgM. Kemudian menyebar ke jaringan retikuloendotelial di seluruh tubuh terutama di hati dan limpa. Dari organ tersebut, $S$. typhi keluar dan berkembang biak di luar sel dalam jaringan 
organ (terutama limpa, usus halus dan kandung empedu) maupun jaringan sinusoid yang dapat menimbulkan radang dan akhirnya demam tinggi (bakteremia II). Proses tersebut, berlangsung antara 7 hingga 10 hari (Handojo, 2004). Selain mekanisme terjadinya demam seperti penjelasan diatas, dapat pula dijelaskan bahwa kuman S. typhi menghasilkan endotoksin yang merupakan kompleks lipopolisakarida dan dianggap berperan penting pada pathogenesis demam tifoid. Endotoksin bersifat pirogenik serta memperbesar reaksi peradangan dimana kuman $S$. typhi berkembang biak. Disamping itu merupakan stimulator yang kuat untuk memproduksi sitokin oleh sel-sel makrofag dan sel leukosit di jaringan yang meradang. Sitokin ini merupakan mediator untuk timbulnya demam dan gejala toksemia (proinflammatory) (Depkes RI, 2006).

Tabel 3. Efektifitas Terapi Antibiotika

\begin{tabular}{|c|c|c|c|c|}
\hline \multirow{2}{*}{ Hasil tes } & \multicolumn{2}{|c|}{ Sebelum terapi } & \multicolumn{2}{|c|}{ Setelah terapi } \\
\hline & $\begin{array}{c}\text { Jumlah } \\
\text { pasien }\end{array}$ & $\%$ & $\begin{array}{c}\text { Jumlah } \\
\text { pasien }\end{array}$ & $\%$ \\
\hline \multicolumn{5}{|l|}{ Widal } \\
\hline Test Normal [(-)negatif Salmonela typhi] & 0 & 0 & 68 & 85 \\
\hline Tidak Normal [(+)positif Salmonela typhi] & 80 & 100 & 12 & 15 \\
\hline \multicolumn{5}{|l|}{ Kadar leukosit } \\
\hline Normal (4000-10.000/mm3) & 38 & 47 & 78 & 97 \\
\hline Tidak Normal (10.000/mm3) & 42 & 53 & 2 & 3 \\
\hline \multicolumn{5}{|l|}{ Suhu tubuh } \\
\hline Normal $\left(36-36,5^{\circ} \mathrm{C}\right)$ & 6 & 7 & 75 & 94 \\
\hline Tidak Normal $\left(>36,5^{\circ} \mathrm{C}\right)$ & 74 & 93 & 5 & 6 \\
\hline \multicolumn{5}{|l|}{ Kesadaran } \\
\hline Normal (sadar penuh) & 55 & 69 & 80 & 100 \\
\hline Tidak Normal (tidak/belum sadar penuh) & 25 & 31 & 0 & 0 \\
\hline \multicolumn{5}{|l|}{ Nyeri perut } \\
\hline Normal (tidak nyeri) & 2 & 2 & 80 & 100 \\
\hline Tidak Normal (ada nyeri) & 78 & 98 & 0 & 0 \\
\hline \multicolumn{5}{|l|}{ Mual/muntah } \\
\hline Normal (tidak mual/muntah) & 2 & 2 & 79 & 99 \\
\hline Tidak Normal (ada mual/muntah) & 78 & 98 & 1 & 1 \\
\hline \multicolumn{5}{|l|}{ Nafsu makan } \\
\hline Normal (ada nafsu makan) & 2 & 2 & 80 & 100 \\
\hline Tidak Normal (tidak/belum nafsu makan) & 78 & 98 & 0 & 0 \\
\hline
\end{tabular}

Persentase tingkat kesadaran pasien yang ditunjukkan pada Tabel 3 diatas adalah normal sebelum pemberian antibiotik yaitu sebesar 69\%, hal ini menunjukkan bahwa kebanyakan pasien masih dalam kondisi kesadaran yang normal atau sadar sepenuhnya (composmentis). Pada Puspa (2005), juga menyatakan bahwa bakteri $S$. typhi itu sendiri adalah bakteri penyebab demam tifoid, selain ditandai dengan demam berkepanjangan (lebih dari satu minggu) juga adanya gangguan saluran cerna dan gangguan kesadaran.

Pada Tabel 3 diatas juga menunjukkan persentase nyeri perut pasien sebelum terapi antibiotik yaitu sebesar $98 \%$, artinya dari data di atas hampir seluruh pasien demam tifoid mengalami nyeri pada perut. Hal ini terjadi karena umumnya penderita demam tifoid akan mengalami keluhan nyeri perut, terutama bagian regio epigastrik atau nyeri ulu hati disertai nausea dan vomitus (mual dan muntah) dan pada kasus yang berat 
biasanya disertai perforasi dan gejala-gejala abdomen akut yakni nyeri perut hebat, kembung serta nyeri pada penekanan atau sering disebut peritonitis (Depkes RI, 2006). Salmonella typhi akan menginjeksi toksin berupa efektor ke dinding intestinum dan mengganggu protein selular serta lipid dan memanipulasi fungsinya. Akibatnya, terjadi fagositosis membran sel epitel sampai bakteri mencapai lamina propria dimana terdapat peyer's patch yang memiliki fungsi sama dengan nodus limfe. Bakteri yang difagosit oleh makrofag akan mengeluarkan mediator inflamasi.

Adanya relaps akan mengakibatkan kerusakan epitel dan perforasi dinding usus membuat inflamasi di dinding intestinum yang terjadi terus menerus. Organ yang mengalami inflamasi jika ditekan akan mengakibatkan rasa nyeri yang hebat. Rasa nyeri juga dapat disebabkan oleh tingginya level gastric acid. Pada saat bakteri masuk ke lambung, mucosal mast cell akan diaktivasi oleh $T$ helper cell sehingga memproduksi histamin. Histamin yang ditangkap oleh reseptor histamin H2 akan berefek meningkatkan asam lambung. Tingginya level asam lambung lama kelamaan dapat mengikis mukosa lambung jika penderita tidak makan secara normal dan dapat menyebabkan rasa nyeri (Playfair dan Chain, 2009).

Persentase mual atau muntah pasien yang ditunjukkan pada Tabel 3 diatas yaitu sebesar 98\% sebelum pemberian antibiotik, artinya hampir seluruh pasien mengalami mual ataupun muntah sebelum diterapi dengan antibiotik. Mual, dapat disebabkan oleh impuls iritatif yang datang dari traktus gastrointestinal, impuls yang berasal dari otak bawah yang berhubungan dengan motion sickness, atau impuls dari korteks serebri untuk mencetuskan muntah. Pada kasus gejala yang dialami penderita demam tifoid, impuls iritatif dari traktus gastrointestinal yang berperan dalam menimbulkan rasa mual.

Bakteri S. typhi yang berkembang biak di dalam traktus gastrointestinal (didalam lamina propria atau peyer's patch) akhirnya akan mengakibatkan usus iritasi dan mengirimkan impuls ke pusat mual dan muntah di otak untuk mencetuskan rasa mual seperti ingin muntah. Dengan sebab yang sama, penderita demam tifoid juga mengalami gangguan nafsu makan. Adapun persentase nafsu makan pasien sebelum terapi antibiotik yaitu sebesar $97 \%$, artinya hampir seluruh pasien mengalami gangguan nafsu makan sebelum diterapi antibiotik.

Pada umumnya pasien demam tifoid akan mengalami gangguan nafsu makan akibat respon imun tubuh yang berlebihan sebagai kompensasi tubuh melawan bakteri $S$. typhi sehingga menyebabkan rasa pahit dan rasa logam di dalam mulut sehingga menyebabkan penurunan nafsu makan (Price, 2006). Adanya bakteri S. typhi pada traktus gastrointestinal, menyebabkan iritasi pada traktus gastrointestinal sehingga meningkatkan ekskresi asam lambung yang ketika dalam posisi tidur asam lambung tersebut dapat naik hingga ke pangkal lidah. Hal inilah yang menyebabkan lidah penderita demam tifoid kotor dan terasa pahit sehingga menyebabkan penurunan nafsu makan. Lidah kotor adalah lidah yang berselaput pada penderita demam tifoid, bagian tengahnya kotor, tengah, tepi dan ujungnya merah, serta tremor. Nyeri ulu hati, mual dan lidah terasa pahit (penurunan nafsu makan) semuanya menandakan adanya sesuatu yang salah berada didalam saluran pencernaan.

Mekanisme nyeri ulu hati, mual dan lidah terasa pahit (penurunan nafsu makan) saling berkaitan dengan peningkatan asam lambung yang diakibatkan oleh adanya respon imunitas tubuh akibat infeksi bakteri Salmonella typhi (Playfair dan Chain, 2009).

\section{Persentase Kesembuhan Setelah terapi Antibiotik}

Berdasarkan hasil penelitian, pada tabel IV ditunjukkan persentase kesembuhan setelah terapi antibiotik yang digunakan di Rumah Sakit Azra Kota Bogor. Terapi antibiotik yang paling banyak digunakan pada kasus demam tifoid di Rumah Sakit Azra Kota Bogor adalah ceftizoxime 1000 mg injeksi yaitu sebanyak 30 pasien. 
Antibiotik lainnya yang sering diresepkan juga digunakan ceftriaxone dan cefepime. adalah levofloxacin dan cefixime, selain itu

Tabel 4. Persentase Kesembuhan

\begin{tabular}{lccc}
\hline \multicolumn{1}{c}{ Antibiotik } & $\begin{array}{c}\text { Jumlah } \\
\text { pemakaian } \\
\text { (pasien) }\end{array}$ & $\begin{array}{c}\text { Jumlah } \\
\text { kesembuhan } \\
\text { (pasien) }\end{array}$ & $\%$ \\
\hline Ceftizoxime 1000 mg Amp & 30 & 26 & 87 \\
Cefepime 1000 mg Amp & 12 & 8 & 67 \\
Ceftriaxone 1000 mg Amp & 9 & 6 & 67 \\
Levofloxacin A 750 mg Amp & 8 & 8 & 10 \\
& & & 0 \\
Levofloxacin A 500 mg Amp & 7 & 6 & 86 \\
Levofloxacin B 500 mg Amp & 7 & 5 & 72 \\
Cefixime 200 mg tab & 4 & 3 & 75 \\
Pefloxacin 400 mg tab & 3 & 2 & 67 \\
\hline TOTAL & 80 & 64 & \\
\hline
\end{tabular}

Berdasarkan hasil pada Tabel 4 diatas, dapat dikatakan bahwa antibiotik yang paling banyak digunakan untuk terapi demam tifoid di Rumah Sakit Azra Kota Bogor adalah antibiotik golongan sefalosporin generasi ketiga yaitu ceftizoxime, ceftriaxone, cefixime dan cefepime. Ceftizoxime stabil terhadap berbagai jenis betalaktamase dan mempunyai spektrum antibakteri yang sangat aktif terhadap berbagai kuman gram positif maupun gram negatif (Syarif et al., 2007). Pada penelitian Anna (2015), menyatakan bahwa antibiotik ceftizoxime masih memberikan efek yang mampu menghambat pertumbuhan bakteri dan berpotensi mengobati masyarakat dari penyakit yang diakibatkan oleh bakteri S. thypi. Antibiotik golongan sefalosporin generasi ketiga lainnya yang juga digunakan seperti ceftriaxone, cefixime dan cefepime memiliki mekanisme kerja yang sama yaitu dengan menghambat sintesis dinding sel mikroba dengan cara menghambat reaksi transpeptidase tahap ke tiga dalam rangkaian reaksi pembentukan dinding sel mikroba (Syarif et al. 007). Antibiotik golongan sefalosporin generasi ketiga merupakan antibiotik spektrum luas dengan kepekaan yang lebih pada gram negatif sehingga dapat digunakan dalam terapi eradikasi infeksi S. thypi (Stoesser, 2013).
Golongan antibiotik terbanyak kedua yang digunakan di Rumah Sakit Azra Kota Bogor adalah golongan fluoroquinolone, yaitu levofloxacin dan pefloxacin. levofloxacin seperti halnya obat golongan fluorokuinolon yang lainnya mempunyai spektrum luas yang efektif melawan bakteri gram negatif dan gram positif, bekerja dengan cara menghambat kerja enzim DNA girase, akibatnya replikasi DNA dapat terhenti (Syarif et al. 2007). Menurut Anna (2015) antibiotik levofloxacin memiliki sensitivitas tinggi dalam menghambat pertumbuhan bakteri salmonella typhi. Selain itu golongan fluorokuinolon juga mencapai penetrasi jaringan yang sangat baik dan dapat membunuh bakteri salmonella typhi di tahap stasioner intraselularnya pada monosit/ makrofag dan mencapai tingkat aktif yang lebih tinggi di kantung empedu dibanding obat lain (Nelwan, 2012).

Golongan antibiotik sefalosporin dan fluorokuinolon yang digunakan untuk terapi pasien demam tifoid di Rumah Sakit Azra Kota Bogor adalah golongan antimikroba lini kedua pengobatan demam tifoid. Pemberian antimikroba lini kedua ini tepat dan dapat dipertimbangkan jika pengobatan dengan antimikroba lini pertama dinilai tidak efektif (Depkes RI, 2006). Tingginya MDR atau Multi Drugs Resistance menyebabkan 
perawatan demam tifoid dengan menggunakan antibiotika pada lini kedua seperti fluorokuinolon atau sefalosporin ini sangat disarankan (Bhutta, 2006). Pada penelitian lain oleh Balaji (2018), juga menyatakan Multi Drug Resistance S. Typhi (resisten terhadap ampisilin, kloramfenikol dan kotrimoksazol) berkurang secara signifikan dengan meningkatnya penggunaan fluoroquinolone di India.

Antibiotik golongan sefalosporin dan fluorokuinolon menjadi pilihan karena saat ini golongan kloramfenikol yang dinyatakan sebagai obat lini pertama tidak lagi digunakan sebagai obat lini pertama karena berkaitan erat dengan tingginya tingkat kekambuhan dan efek samping yang ditimbulkan. Adapun beberapa efek samping yang dapat ditimbulkan dari penggunaan kloramfenikol pada pasien dewasa maupun anak yaitu supresi sumsum tulang, grey baby syndrome, neuritis optik pada anak, pertumbuhan candida di saluran cerna, dan timbulnya ruam (Depkes RI, 2011). Efikasi terhadap pembersihan waktu demam pada pasien yang diberikan golongan sefalosporin dan fluorokuinolon menjadikan tolak ukur yang setara atau lebih baik dibandingkan dengan semua antimikroba lainnya (Thompson, 2017).

Berdasarkan data hasil penelitian pada Tabel 4 juga ditunjukkan persentase kesembuhan setelah pemberian antibiotik berurutan dari yang paling tinggi adalah $100 \%$ pada levofloxacin A $750 \mathrm{mg}$ inj, 87\% pada ceftizoxime $1000 \mathrm{mg}$ inj, $86 \%$ pada levofloxacin A $500 \mathrm{mg}, 75 \%$ pada cefixime $200 \mathrm{mg}$ tab, $72 \%$ pada levofloxacin B 500 $\mathrm{mg}$, dan $67 \%$ masing-masing pada cefepime $1000 \mathrm{mg}$ Inj, ceftriaxone $1000 \mathrm{mg}$ Inj, dan pefloxacin $400 \mathrm{mg}$ tab. Dapat dilihat dari perolehan data tersebut, rute pemberian antibiotika yang digunakan dalam penelitian ini paling banyak adalah secara intravena. Pemberian antibiotika secara peroral seharusnya menjadi pilihan pertama untuk terapi infeksi (Depkes RI, 2011), namun pada pasien yang mengalami kehilangan nafsu makan, sembelit ataupun diare, pemberian secara oral tidak akan memberikan efek optimal, sehingga pada infeksi yang sedang hingga berat penggunaan antibiotika secara intravena dapat dipertimbangkan (WHO, 2003). Pada penelitian ini persentase kesembuhan tertinggi terjadi pada antibiotika golongan fluorokuinolon levofloxacin A 750 mg injeksi sebesar $100 \%$, diikuti levofloxacin A $500 \mathrm{mg}$ injeksi $86 \%$ dan levofloxacin B $500 \mathrm{mg}$ injeksi $72 \%$. Hal ini kemungkinan disebabkan karena perbedaan kondisi infeksi yang diderita pasien atau berat ringannya tanda dan gejala yang diderita, berkaitan dengan perbedaan imunitas tubuh dalam merespon infeksi bakteri salmonella typhi, sehingga dosis $750 \mathrm{mg}$ injeksi memberikan hasil persentase kesembuhan lebih tinggi dibandingkan dosis $500 \mathrm{mg}$ injeksi.

Penatalaksanaan demam tifoid 2010, merekomendasikan penggunaan levofloxacin, baik untuk kasus ringan maupun berat. Untuk kasus ringan diberikan levofloxacin 500 $\mathrm{mg}$ /hari secara oral selama 7 hari, sedangkan untuk kasus berat diberikan levofloxacin 500 mg secara intravena selama 3-5 hari (Hidayati, 2011).

Menurut Nelwan RHH (2012), berbagai studi telah dilakukan untuk menilai efektivitas fluoroquinolone dan salah satu fluoroquinolone yang saat ini telah diteliti dan memiliki efektivitas yang baik adalah levofloxacin. Studi komparatif, acak, dan tersamar tunggal telah dilakukan untuk levofloxacin terhadap obat standar ciprofloxacin untuk terapi demam tifoid tanpa komplikasi. Levofloxacin diberikan dengan dosis $500 \mathrm{mg}, 1$ kali sehari dan ciprofloxacin diberikan dengan dosis $500 \mathrm{mg} 2$ kali sehari masing-masing selama 7 hari. Kesimpulan dari studi ini adalah bahwa pada saat ini levofloxacin lebih bermanfaat dibandingkan ciprofloxacin dalam hal waktu penurunan demam, hasil mikrobiologi dan secara bermakna memiliki efek samping yang lebih sedikit dibandingkan ciprofloxacin. Selain itu, pada studi terbuka mengenai efikasi dan keamanan levofloxacin pada terapi demam tifoid tanpa komplikasi, levofloxacin diberikan dengan dosis $500 \mathrm{mg}, 1$ kali sehari selama 7 hari. Efikasi klinis yang dijumpai pada studi ini adalah $100 \%$ dengan efek 
samping yang minimal. Dari studi ini juga terdapat tabel perbandingan rata-rata waktu penurunan demam di antara berbagai jenis fluoroquinolone yang beredar di Indonesia di mana penurunan demam pada levofloxacin paling cepat, yaitu 2,4 hari (Nelwan, 2006). Sebuah meta-analisis yang dipublikasikan pada tahun 2009 menyimpulkan bahwa pada demam enterik dewasa, fluoroquinolone lebih baik dibandingkan kloramfenikol untuk mencegah kekambuhan. Pasien dengan muntah yang menetap, diare berat, distensi abdomen, atau kesadaran menurun memerlukan rawat inap dan pasien dengan gejala klinis tersebut diterapi sebagai pasien demam tifoid yang berat (Nelwan, 2006). Terapi antibiotik yang diberikan pada demam tifoid berat menurut WHO tahun 2003 dapat dilihat, walaupun di tabel tersebut tertera cefotaxime untuk terapi demam tifoid tetapi sayangnya di Indonesia sampai saat ini tidak terdapat laporan keberhasilan terapi demam tifoid dengan cefotaxime.

Pasien dewasa dengan demam tifoid idealnya akan mengalami perbaikan klinis dalam 3-7 hari (Depkes RI, 2006), namun menurut guideline WHO (2003), penanganan demam tifoid durasi atau lama pemberian antibiotika rata-rata 5-14 hari tergantung dari jenis antibiotika yang digunakan. Pada penelitian ini durasi pemberian antibiotika untuk menangani demam tifoid adalah selama 3-5 hari $(71 \%)$ dan lebih dari 5 hari (29\%) (Tabel I). Hal ini dapat dikatakan wajar terjadi karena penanganan kasus demam tifoid umumnya dirawat selama 3-7 hari (Depkes RI, 2006), dimana lama pemberian terapi antibiotik berdasarkan pada perbaikan data mikrobiologis, kondisi pasien, dan data klinis lainnya (Depkes RI, 2006).

\section{KESIMPULAN}

Berdasarkan hasil penelitian Evaluasi Pemberian Antibiotik pada Pasien Demam Tifoid yang telah dilakukan di Rumah Sakit Azra Kota Bogor maka dapat disimpulkan bahwa penggunaan antibiotik untuk terapi demam tifoid di Rumah Sakit Azra Kota Bogor efektif terhadap pasien, dengan persentase widal test sebesar $85 \%$ normal, kadar leukosit sebesar 97\% normal, suhu tubuh sebesar 94\% normal, tingkat kesadaran sebesar $100 \%$ normal, nyeri perut sebesar $100 \%$ normal, mual atau muntah sebesar 99\% normal, nafsu makan diperoleh sebesar 100\% normal.

\section{Ucapan Terimakasih}

Kami ucapkan terimakasih kepada semua pihak pada Rumah Sakit Adzra Kota Bogor, khususnya Manajer SDM dan Pendidikan, yang telah memberikan izin untuk melakukan kegiatan penelitian dan memberikan informasi data kesehatan pasien di Rumah Sakit Azra Kota Bogor. Semoga Allah SWT membalasnya sebagai amalan ibadah, Aamiin.

\section{DAFTAR PUSTAKA}

Anna, Y. 2015. Uji Sensitifitas Antibiotik Levofloxacin Yang Ada Di Pasaran Terhadap Bakteri Salmonella thyphosa ATCC 2401. Skripsi. Program Studi Farmasi, Sekolah Tinggi Ilmu Kesehatan Bakti Tunas Husada.

Balaji, V., Agila K.P., Yamuna, D. Bakhthavatchalam, B. \& Ravikar, R. 2018. Typhoid fever: issues in laboratory detection, treatment options $\&$ concerns in management in developing countries ; $2018 \mathrm{Jul}$; 4(6): FSO312, [internet], [cited 2020 June 6], available from: https://www.ncbi.nlm.nih.gov/pmc/arti cles/PMC6060388/

Bhutta, Z. A. 2006. Typhoid fever: current concepts. Infect Dis Clin Pract, 14: 266-72.

Departemen Kesehatan Republik Indonesia. 2006. Pedoman Pengendalian Demam Tifoid. Kementrian Kesehatan RI.

Departemen Kesehatan Republik Indonesia. 2011. Pedoman Umum Penggunaan Antibiotika. Peraturan Menteri Kesehatan Republik Indonesia. Kementrian Kesehatan RI.

Farihatun, N. 2017. Diagnosa Demam Tifoid Disertai Kondisi Kadar Leukosit Pasien di RS Islam Sakinah Mojokerto. 
Skripsi. Universitas Islam Negeri Sunan Ampel.

Fatmawati, R. 2011. Uji Diagnostik Tes Serologi Widal Dibandingkan Dengan Kultur Darah Sebagai Baku Emas Untuk Diagnosis Demam Tifoid Pada Anak Di RSUP Dr. Kariadi Semarang. Skripsi. Universitas Diponegoro.

Hadinegoro, S.R.H \& Satari H.I. 1999. Pelatihan Bagi Pelatih Dokter Spesialis Anak dan Dokter Spesialis Penyakit Dalam. Fakultas Kedokteran Universitas Indonesia.

Handojo, I. 2004, Imunoasai Terapan pada Beberapa Penyakit Infeksi. Universitas Airlangga Press.

Hidayati, H. 2011. Perkembangan terkini terapi demam tifoid. Medika Jurnal Kedokteran Indonesia [serial online]. Available from: URL: http://www.jurnalmedika.com/edisitahun-2011/edisi-no-09-vol-xxxvii2011/363-kegiatan/727-perkembanganterkini-terapi-demam-tifoid.

Juwono, R. 2004. Demam tifoid dalam Buku Ajar Ilmu Penyakit Dalam Jilid 1 Edisi 3. Balai Penerbit FKUI.

Nelwan, R.H.H. 2012. Tata laksana terkini demam tifoid. Continuing Medical Education, 39(4): 247-250.

Nelwan, R.H.H., Chen K., Nafrialdi N. Paramita D. 2006. Open study on efficacy and safety of levofloxacin in treatment of uncomplicated typhoid fever. Southeast Asian J Trop Med Public Health, 37(1): 126-130.

Playfair \& Chain. 2009. At a Glance: Imunologi Edisi Sembilan. Erlangga Medical Series.

Price, P. \& Sylvia A. 2006. Patofisologi Konsep Klinis Proses-proses Penyakit Jilid 2. Penerbit EGC.

Puspa, W., Prihartini P., Probohoesodo M.Y. 2005. Kemampuan uji Tabung Widal Menggunakan Antigen Import Dan Antigen Lokal. Indonesian Journal of Clinical Pathology and Medical Laboratory, 12: 1.
Rampengan, N. H. 2013. Antibiotik terapi demam tifoid tanpa komplikasi pada anak. Sari Pediatr, 14(5): 271-272.

Sastramihardja, S. \& Herry S. 2001. Penggunaan obat yang rasional di tempat pelayanan kesehatan. Majalah Kedokteran Indonesia, 47: 532 - 536.

Stoesser, N., Eyre D., Basnyat B. \& Parry C. 2013. Treatment of enteric fever (thypoid and paratyphoid fever) with third and fourth generation cephalosporins. Cochrane Database of Systematic Reviews.

Syarif, A., Ascobat P., Estuningtyas A., Setiabudy R. 2007. Farmakologi dan Terapi Edisi Lima. Universitas Indonesia.

Tan, H.T. \& Rahardja K. 2015. Obat-Obat Penting Khasiat Penggunaan dan Efek Efek Sampingnya Edisi VII. Departemen Kesehatan Republik Indonesia.

Thompson, C. N., Abhilasha K., Sabina D., Amit A., Marcel W., Thomas D., Jeremy J. F., et al. 2017. Treatment Response in Enteric Fever in an Era of Increasing Antimicrobial Resistance. An Individual Patient Data Analysis of 2092 Participants Enrolled into 4 Randomized Controlled Trials in Nepal. Clinical Infectious Desease, 64(1) :1522-1531.

Wahyu, W. A. 2016. Evaluasi Penggunaan Dan Efektifitas Pemberian Antibiotik Pada Pasien Demam Tifoid Di Instalasi Rawat Inap RSUD Sukoharjo periode 1 oktober - 31 Desember 2015. Skripsi. Fakultas Farmasi Universitas Muhammadiyah Surakarta.

WHO. 2003. Background document: The diagnosis, treatment, and prevention of typhoid fever/

https://www.glowm.com/pdf/WHO CustomLicense.pdf. Diakses tanggal 5 Mei 2020.

Widodo, J. 2006. Demam Tifoid dalam Buku Ajar Ilmu Penyakit Dalam. Pusat Penerbitan Departemen Ilmu Penyakit Dalam FKUI. 